\title{
Prevention of Lung Bacterial Colonization With a Leak-Proof Endotracheal Tube Cuff: An Experimental Animal Study
}

\author{
Emanuele Rezoagli, Massimo Cressoni, Giacomo Bellani, Giacomo Grasselli, Antonio M Pesenti, \\ Theodor Kolobow, ${ }^{\dagger}$ and Alberto Zanella
}

\begin{abstract}
BACKGROUND: Endotracheal tubes with standard polyvinyl chloride cuffs create folds on inflation into the trachea, which lead to potential leakage of subglottic secretions into the lower airways and cause lung colonization and pneumonia. The use of a double-layer prototype leak-proof cuff has shown effective prevention of the fluid leakage across the cuff. We hypothesized that the use of such a leak-proof cuff could prevent lung bacterial colonization in vivo. METHODS: To simulate patients in the ICU, 13 pigs were placed in the semirecumbent position, intubated, and mechanically ventilated for $72 \mathrm{~h}$. Five animals were prospectively intubated with an endotracheal tube with a leak-proof cuff (leak-proof cuff group). Data from 8 animals previously intubated with an endotracheal tube with a standard polyvinyl chloride cuff (standard cuff group) were retrospectively analyzed. Leakage of tracheal secretions across the leak-proof cuff was tested by the macroscopic methylene blue evaluation. Arterial blood gas exchanges and microbiology were tested in all the pigs at necropsy. RESULTS: In the standard cuff group, all the pigs showed heavy bacterial colonization of the lungs after $72 \mathrm{~h}$ of mechanical ventilation, with an overall proportion of colonized lung lobes of $92 \%$ (44/48 lobes, $8 / 8$ animals) compared with $27 \%$ ( $8 / 30$ lobes, $5 / 5$ animals) in the leak-proof cuff group $(P<.001)$. These results were strengthened by the absence of methylene blue in the tracheal secretions below the leak-proof cuff. Furthermore, no hypoxemia was demonstrated in the pigs in the leak-proof cuff group after the 72-h experiment $\left(\mathrm{P}_{\mathrm{aO}_{2}} / \mathrm{F}_{\mathrm{IO}_{2}}\right.$ change from baseline, leak-proof cuff group vs standard cuff group; median difference 332, 95\% CI 41-389 mm Hg; $P=.030$ ). CONCLUSIONS: A new leak-proof cuff for endotracheal intubation prevented macroscopic leakage of subglottic secretions along the airways. This mechanism led to the reduction of lung bacterial colonization, which could contribute to the prevention of hypoxemia in the pigs on mechanical ventilation while in the semirecumbent position. Key words: endotracheal tube cuff; bacterial colonization; acute hypoxemic respiratory failure; ventilator-associated pneumonia. [Respir Care 2019;64(9):1031-1041. (C) 2019 Daedalus Enterprises]
\end{abstract}

\section{Introduction}

Ventilator-associated pneumonia (VAP) is a nosocomial infection that develops in patients on mechanical ventila- tion for $>48 \mathrm{~h} .{ }^{1}$ VAP has an overall attributable mortality of $13 \%$, which can reach up to $69 \%$ in surgical patients. ${ }^{2}$ The presence of a endotracheal tube (ETT) is the leading cause of VAP. ${ }^{2,3}$ In the ICU, patients who are critically ill and who are sedated, intubated, and on mechanical venti-
Drs Rezoagli, Cressoni, and Bellani are affiliated with the School of Medicine and Surgery, University of Milano-Bicocca, Monza, Italy. Dr Rezoagli is affiliated with the Regenerative Medicine Institute at CÚRAM Centre for Research in Medical Devices, National University of Ireland, Galway, Ireland. Dr Rezoagli is affiliated with the Discipline of Anaesthesia, School of Medicine, National University of Ireland, Galway, Ireland. Dr Rezoagli is affiliated with the Department of Anesthesia and Intensive Care Medicine, Galway University Hospitals, SAOLTA University Health Group, Galway, Ireland. Dr Bellani is affiliated with the

\footnotetext{
Department of Emergency and Intensive Care, San Gerardo Hospital, Monza, Italy. Drs Grasselli, Pesenti, and Zanella are affiliated with Dipartimento di Fisiopatologia Medico-Chirurgica e dei Trapianti, Università degli Studi di Milano, Milan, Italy. Drs Grasselli, Pesenti, and Zanella are affiliated with Dipartimento di Anestesia, Rianimazione ed Emergenza Urgenza, Fondazione IRCCS Ca' Granda - Ospedale Maggiore Policlinico, Milan, Italy. At the time of this research, Dr Kolobow was affiliated with the National Institutes of Health, Bethesda, MD.
} 
lation are usually in the semirecumbent position. Preclinical studies with large animal models in the semirecumbent position showed that gravity is the key factor that determines leakage of the subglottic secretions along the airways, despite the presence of an ETT cuff.4-7 The lack of a complete seal with an ETT cuff may allow lung colonization and serve as a source for VAP or postextubation pneumonia. $^{8}$

\section{See the Related Editorial on Page 1170}

In previous preclinical studies, our group demonstrated the limitations of the high-volume low-pressure polyvinyl chloride (PVC) cuffs in different experimental conditions. ${ }^{9-11}$ In an in vitro bench-top study, ${ }^{9}$ high-volume low-pressure PVC cuffs were not able to prevent fluid leakage, even at inflation cuff pressures as high as $50 \mathrm{~cm} \mathrm{H}_{2} \mathrm{O}$. Conversely, an ETT cuff prototype made with a double-layer guayule latex cuff (leak-proof cuff) completely prevented fluid leakage even at inflation pressures as low as $20 \mathrm{~cm} \mathrm{H}_{2} \mathrm{O}$ for 24 h. ${ }^{9}$ The leak-proof cuff showed a superior performance compared with the high-volume low-pressure PVC cuff also in preventing fluid leakage when no positive pressure was applied. ${ }^{10}$ Furthermore, in an experimental animal model of pigs intubated with an ETT with a high-volume low-pressure PVC cuff and on mechanical ventilation for $72 \mathrm{~h}$ without antibiotic administration or bacterial instillation into the trachea, we observed the development of massive lung bacterial colonization. ${ }^{7}$

Therefore, we hypothesized that, in the absence of exogenous bacteria inoculation along the airways and without antibiotic prophylaxis, a leak-proof cuff could prevent lung bacterial colonization in an experimental pig model enterally fed and on mechanical ventilation for $72 \mathrm{~h}$, which simulates the semirecumbent position of patients in the ICU. In this investigation, we aimed to assess the effects

\section{$\dagger$ Deceased.}

This study was supported by the National Research Program, National Heart, Lung, and Blood Institute, National Institutes of Health, Intramural Research, Bethesda Maryland.

The study was performed at the animal laboratory of the National Institutes of Health in Bethesda, MD, directed by Dr Kolobow.

The authors have disclosed no conflicts of interest.

Correspondence: Alberto Zanella MD, Dipartimento di Anestesia, Rianimazione ed Emergenza Urgenza, Fondazione IRCCS Ca' Granda - Ospedale Maggiore Policlinico, Dipartimento di Fisiopatologia medicochirurgica e dei trapianti, Università degli Studi di Milano, Via Francesco Sforza 35, Milan 20122, Italy. E-mail: alberto.zanella1@unimi.it.

DOI: $10.4187 /$ respcare. 06573

\section{QUICK LOOK}

\section{Current knowledge}

Endotracheal tubes with standard high-volume lowpressure polyvinyl chloride cuffs result in folds on inflation into the trachea, which do not provide an effective seal. The presence of cuff folds leads to potential leakage of subglottic secretions into the lower airways in the semirecumbent position due to the gravitational effect and causes lung colonization and pneumonia. The use of a double-layer prototype leak-proof cuff showed effective prevention of the fluid leakage across the cuff in vitro.

\section{What this paper contributes to our knowledge}

In pigs on mechanical ventilation for $72 \mathrm{~h}$ while in the semirecumbent position, a new leak-proof cuff for endotracheal intubation prevented macroscopic leakage of subglottic secretions into the airways. This mechanism reduced lung bacterial colonization in the lungs, as shown by the microbiologic findings, the absence of methylene blue below the endotracheal tube cuff, and the prevention of hypoxemic respiratory failure.

of an ETT with a leak-proof cuff on the prevention of lung bacterial colonization (primary end point) and acute hypoxemic respiratory failure (secondary end point) in an animal model in the semirecumbent position, with continuous enteral feeding and mechanical ventilation for $72 \mathrm{~h}$ and without any antibiotic treatment.

\section{Methods}

\section{Housing and Husbandry}

Animal experiments were conducted in accordance to the Institutional Animal Care and Use Committee at the National Institutes of Health Animal Research Laboratory, Bethesda, MD, where the study has been approved and conducted. National Institutes of Health guidelines were followed. ${ }^{12}$ The animals were housed in the stables of the animal laboratory of the National Institutes of Health (Bethesda, Maryland). The large animal stable housed multiple animals, and multiple animals were not separated into single cages. The bedding material was composed of wood shavings, wheat, and barley straw. The environmental temperature was kept at $70^{\circ} \mathrm{F}$. The animals had free access to food and water. Before starting the experiment, animal welfare was assessed daily and behavioral changes, if present, were immediately reported to the responsible veterinarian of the National Institutes of Heath animal laboratory. 


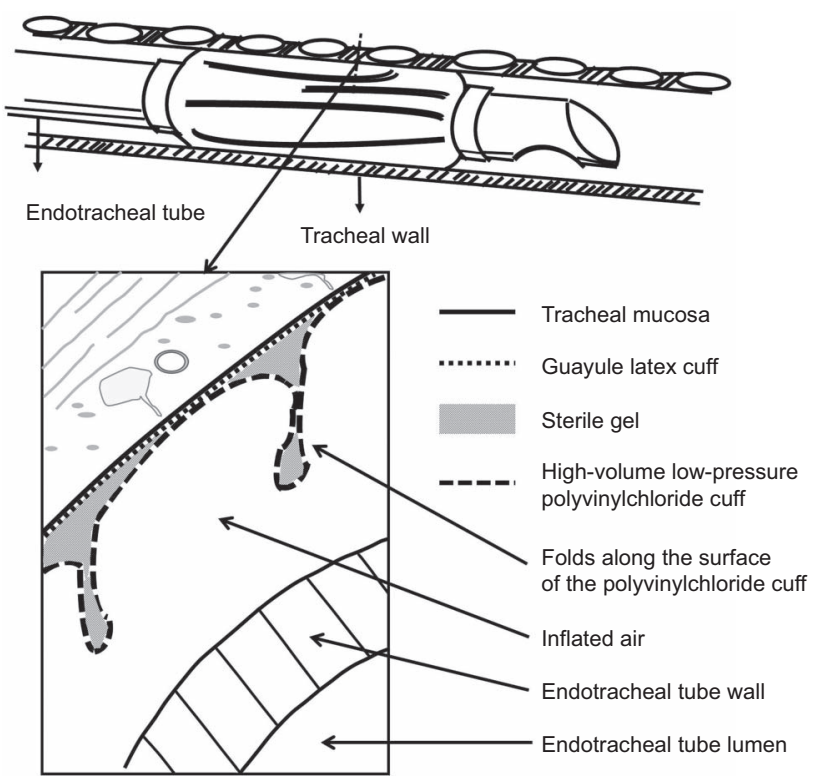

Fig. 1. Prototype experimental leak-proof cuff. A layer of highly compliant guayule latex (dotted line) is draped around a standard high-volume low-pressure polyvinyl chloride cuff (dashed line). A sterile gel was added between the 2 cuffs.

\section{Tracheal Orientation and Animal Preparation}

Nothing by mouth status was maintained for $12 \mathrm{~h}$ before animal preparation and intubation in both groups. We intubated and mechanically ventilated 5 adult female $\mathrm{Yu}-$ catan miniature pigs. Animals were purchased by the staff of the animal laboratory (National Heart, Lung, and Blood Institute, National Institutes of Health, in Bethesda, Maryland) in the prone position for $72 \mathrm{~h}$. Propofol $(2-6 \mathrm{mg} / \mathrm{kg} / \mathrm{h}$ ) and fentanyl (2-20 $\mu \mathrm{g} / \mathrm{kg} / \mathrm{h})$ were continuously infused to maintain general anesthesia. After anesthesia administration, at the time of orotracheal intubation, we intubated the animals with a Mallinkrodt Hi-Lo (Mallinckrodt, StainesUpon-Thames, UK) with a guayule latex cuff of cylindrical shape (13 mm diameter) and 50-60 $\mu \mathrm{m}$ thick (Yulex, Maricopa, Arizona) draped over the Mallinckrodt Hi-Lo (inner diameter, $7.5 \mathrm{~mm}$ ) ETT cuff (Mallinckrodt) (leakproof cuff). A sterile gel $(0.5 \mathrm{~mL})$ (Surgilube, Altana, Melville, New York) was added between the 2 cuffs to allow an equal distribution of inflation pressure and to minimize friction among the cuffs (Fig. 1). Therefore, the leak-proof cuff could dilate at low pressures and adhere to the tracheal mucosa without developing folds. ${ }^{9}$ We named this group the leak-proof cuff group, and the animals received enteral feeding $(30 \mathrm{~mL} / \mathrm{h})$ through an orogastric tube (Osmolite, diluted 1:1 with tap water, Ross Nutrition, Abbott Laboratories, Columbus, Ohio).

We further evaluated, retrospectively, the data of 8 animals that we intubated with an ETT by using a cylindrical shaped high-volume low-pressure cuff (Mallinkrodt Hi-
Lo, inner diameter $7.5 \mathrm{~mm}$ ), an historical control group (no. $=8$, two of which received enteral nutrition). ${ }^{7}$ The leak-proof cuff group was studied by the same investigators (MC, TK, and $\mathrm{AZ}$ ) and in the same laboratory of the historical control (standard cuff group). ${ }^{7}$ Beside the study treatment (ETT cuff), the 2 groups only differed by the presence of enteral nutrition (all the animals in the leakproof cuff group [no. $=5$ ] and 2 of 8 animals in the historical control group). Enteral nutrition is an established risk factor of lung colonization and pneumonia, ${ }^{13-16}$ which could further challenge the performance of the leak-proof cuff compared with the standard cuff.

The ETT and the trachea were oriented $45^{\circ}$ above the horizontal to simulate the semirecumbent position of patients who are intubated while in the ICU. The animals' position and preparation were performed according to Zanella et $\mathrm{al}^{7}$ as previously described. In summary, the extrathoracic part of the trachea runs in parallel with the ventral portion of the animal's neck, the intrathoracic part of the trachea designs an angle of $11^{\circ}$ with the spine. To obtain the ETT and the trachea oriented $45^{\circ}$ above the horizontal and to simulate a model of the semirecumbent position, the upper part of the bed was angulated $30^{\circ}$ above horizontal and a foam pillow was positioned beneath the head of the animal. The study design is depicted in Figure 2.

\section{Animal Handling}

Animals in the leak-proof cuff group underwent the same handling as the standard cuff group. ${ }^{7}$ Briefly, mechanical ventilation was adjusted to reach a stable $\mathrm{P}_{\mathrm{aCO}_{2}} \sim 40 \mathrm{~mm} \mathrm{Hg}$ with a tidal volume of $6-8 \mathrm{~mL} / \mathrm{kg}$, with a breathing frequency that ranged from 10 to 20 breaths/min, with an average of $\sim 14$ breaths/min. PEEP was $5 \mathrm{~cm} \mathrm{H}_{2} \mathrm{O}$. The endotracheal cuff pressure was kept within a range of 25$30 \mathrm{~cm} \mathrm{H}_{2} \mathrm{O}$ and was checked every $6 \mathrm{~h}$ from the start of the experiment by using a manual manometer. An open tracheal suction system was used to perform endotracheal suctioning in both groups every $6 \mathrm{~h}$. Neither group was treated with antibiotics either before ( $\geq 1$ month earlier) or throughout the study, and no bacteria was instilled into the trachea. In the leak-proof cuff group, the presence of macroscopic aspiration across the ETT cuff was further evaluated by methylene blue injection in the supraglottic space 2 times a day. The presence of blue was detected in the tracheal suction at each tracheal aspiration and in the trachea with a bronchoscope 1 and $3 \mathrm{~h}$ after methylene blue injection. Recordings of blood gas analyses, plateau pressure, breathing frequency, and mean arterial pressure were obtained at the beginning and at the end of the experiment $(72 \mathrm{~h})$. Hypoxemia was defined as an $\mathrm{P}_{\mathrm{aO}_{2}} / \mathrm{F}_{\mathrm{IO}_{2}}$ of $<300 \mathrm{~mm} \mathrm{Hg}$. 


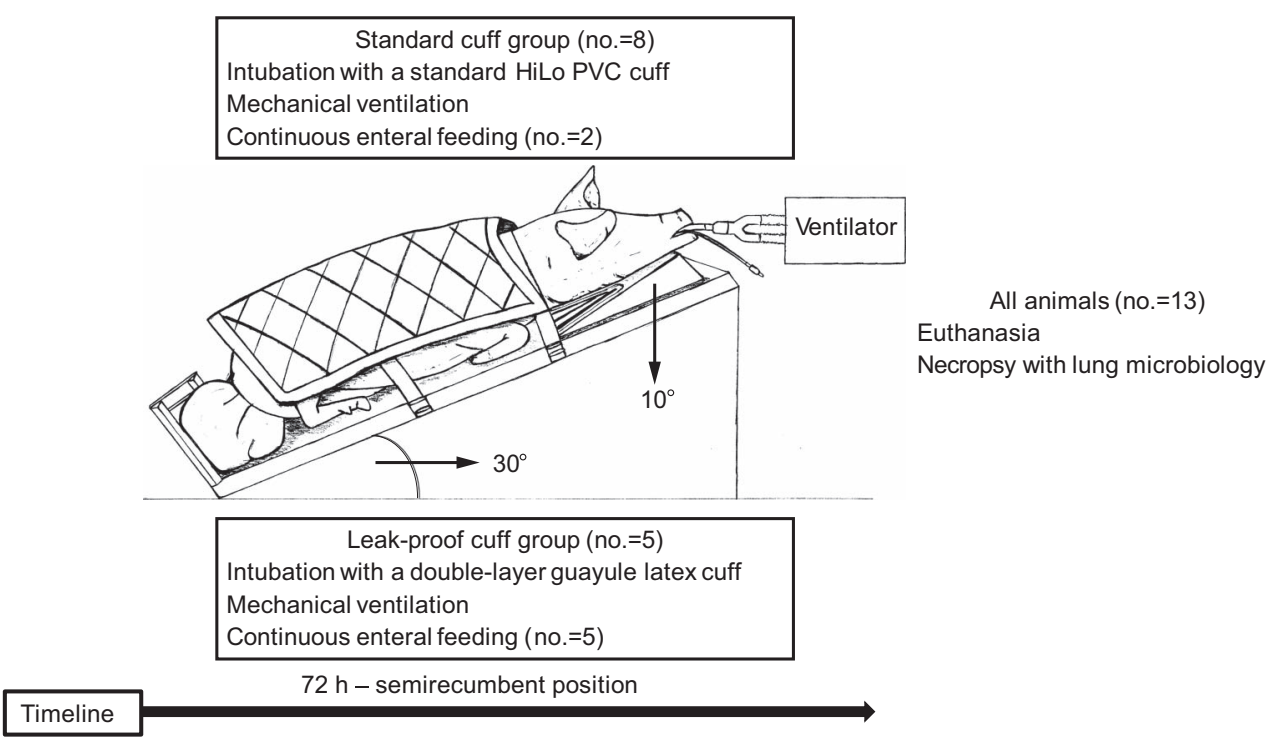

Fig. 2. Study design.

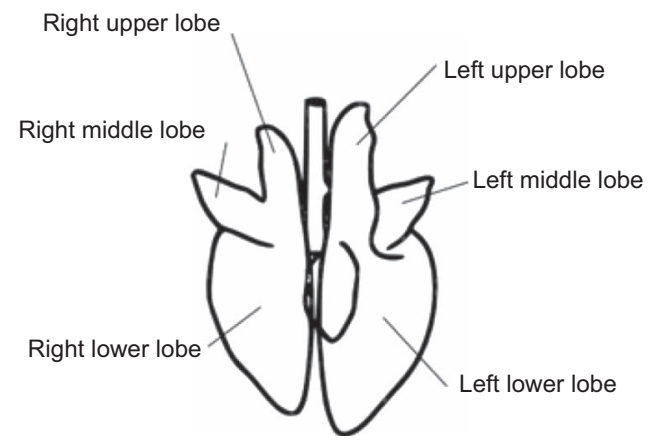

Fig. 3. Description of the 6 sampling sites for microbiologic evaluation along the lungs.

\section{Autopsy and Microbiologic Sampling}

All the animals underwent non-recovery procedures. Euthanasia was performed by using an anesthetic overdose (intravenous pentobarbitone) according to the American National Institutes of Health guidelines ${ }^{12}$ and to Annex IV of the European Directive 2010/63/EU. ${ }^{17}$ Autopsy was performed after $72 \mathrm{~h}$ of mechanical ventilation in all the animals. Removal of the trachea and lungs during autopsy and microbiologic samplings were aseptically performed, as previously described. ${ }^{7}$ Concisely, lung tissue samples were excised from the innermost portions of each of the 6 lobes (Fig. 3). Lung samples for microbiologic analysis were shipped to the National Institutes of Health microbiology laboratory to evaluate the presence and quantify the levels of the bacterial load (Table 1). Bacteria colonization was expressed as colony-forming unit (CFU) per grams in each tissue sample. Bacterial colonization was defined in the presence of a bacterial load of $\geq 10^{3} \mathrm{CFU} / \mathrm{g}$.

\section{Statistical Analysis}

Gas Exchanges and Physiologic Variables. Data normality was assessed with the Shapiro-Wilk test. Continuous physiologic variables (blood gas analyses [arterial $\mathrm{pH}$ ]), $\mathrm{P}_{\mathrm{aCO}_{2}}, \mathrm{P}_{\mathrm{aO}_{2}} / \mathrm{F}_{\mathrm{IO}_{2}}$, respiratory system plateau pressures, breathing frequency, and mean arterial pressure were expressed as median (interquartile range) at different time points (baseline and $72 \mathrm{~h}$ ). The change of the variables from baseline in each group was expressed as median (95\% CI) difference (Table 2). To test the hypothesis that the leak-proof ETT cuff (exposure variable) may prevent acute hypoxemic respiratory failure (outcome variable) after $72 \mathrm{~h}$ of intubation and mechanical ventilation, the change in continuous physiologic variables over time was compared by using a 2-way analysis of variance for repeated measurements ( $72 \mathrm{~h}$ vs baseline) by testing the difference between the groups (leak-proof vs standard cuff groups) on the mean change from baseline (group-bytime interaction) (Fig. 4). The Bonferroni correction was used for post hoc comparisons. In addition, the difference of the differences between $72 \mathrm{~h}$ and baseline among the groups (leak-proof vs standard cuff groups) was reported as the median and 95\% CI difference, and the $P$ value, which compared the differences of the changes from $72 \mathrm{~h}$ to baseline between the groups was calculated by using the Mann-Whitney $U$ test (Table 2).

Microbiologic Colonization. Locations were expressed in terms of lung lobes ( 6 locations $=6$ lobes). The bacterial load assessed within different animals (pig level) or within different colonized lung lobes (lung lobe level) was described as median (interquartile range) 
Prevention of Colonization With a Leak-Proof ETT Cuff

Table 1. Lung Pathogenic Bacterial Load and Bacterial Colonization

\begin{tabular}{|c|c|c|c|c|c|c|c|}
\hline Pig no. & Species & RUL & RML & RLL & LUL & LML & LLL \\
\hline \multicolumn{8}{|c|}{ Standard cuff group } \\
\hline \multirow[t]{3}{*}{5620} & Aerococcus urinae & - & - & - & - & $1.0 \mathrm{E}+05$ & $5.0 \mathrm{E}+06$ \\
\hline & Corynebacterium genitalium & - & - & - & - & - & $3.6 \mathrm{E}+03$ \\
\hline & Corynebacterium species & - & $1.4 \mathrm{E}+06$ & $5.2 \mathrm{E}+07$ & - & $3.5 \mathrm{E}+05$ & $3.1 \mathrm{E}+07$ \\
\hline \multirow[t]{2}{*}{5621} & C. genitalium & $8.3 \mathrm{E}+05$ & - & - & - & - & - \\
\hline & Corynebacterium species & $9.3 \mathrm{E}+07$ & $2.7 \mathrm{E}+09$ & $1.9 \mathrm{E}+09$ & $1.5 \mathrm{E}+09$ & $1.4 \mathrm{E}+09$ & $2.8 \mathrm{E}+08$ \\
\hline \multirow[t]{2}{*}{5639} & Stomatococcus mисilaginosus & $8.4 \mathrm{E}+04$ & $4.4 \mathrm{E}+07$ & $1.3 \mathrm{E}+07$ & $5.0 \mathrm{E}+07$ & $8.9 \mathrm{E}+07$ & $2.2 \mathrm{E}+08$ \\
\hline & Streptococcus suis & $3.7 \mathrm{E}+03$ & $4.0 \mathrm{E}+06$ & $1.2 \mathrm{E}+06$ & $2.1 \mathrm{E}+07$ & $3.1 \mathrm{E}+07$ & $4.7 \mathrm{E}+07$ \\
\hline \multirow[t]{2}{*}{5644} & Oerskovia species & $1.8 \mathrm{E}+08$ & $1.1 \mathrm{E}+09$ & $2.5 \mathrm{E}+08$ & $1.4 \mathrm{E}+07$ & $1.1 \mathrm{E}+09$ & $4.6 \mathrm{E}+06$ \\
\hline & Streptococcus cristatus & $2.3 \mathrm{E}+06$ & $2.8 \mathrm{E}+03$ & $5.6 \mathrm{E}+06$ & $1.1 \mathrm{E}+05$ & $1.3 \mathrm{E}+07$ & $3.0 \mathrm{E}+04$ \\
\hline \multirow[t]{2}{*}{5652} & Escherichia coli & $1.7 \mathrm{E}+03$ & $3.2 \mathrm{E}+03$ & $1.2 \mathrm{E}+03$ & - & - & - \\
\hline & Staphylococcus epidermidis & - & - & - & $2.3 \mathrm{E}+03$ & - & - \\
\hline \multirow[t]{3}{*}{5661} & Acinetobacter species & $5.6 \mathrm{E}+07$ & - & $8.0 \mathrm{E}+07$ & $1.0 \mathrm{E}+06$ & - & $4.7 \mathrm{E}+06$ \\
\hline & Arcanobacterium pyogenes & - & $2.0 \mathrm{E}+07$ & - & - & $4.2 \mathrm{E}+07$ & - \\
\hline & Corynebacterium species & $1.1 \mathrm{E}+09$ & $5.3 \mathrm{E}+07$ & $7.2 \mathrm{E}+08$ & $7.1 \mathrm{E}+06$ & $5.9 \mathrm{E}+07$ & $7.7 \mathrm{E}+07$ \\
\hline \multirow[t]{7}{*}{8057} & Brevundimonas vesicularis & $5.9+07$ & $1.2 \mathrm{E}+06$ & $8.7 \mathrm{E}+07$ & $1.0 \mathrm{E}+03$ & $3.2 \mathrm{E}+03$ & - \\
\hline & Streptococcus sanguinis & - & $5.0 \mathrm{E}+06$ & - & - & - & - \\
\hline & Streptococcus intermedius & - & - & - & - & $1.1 \mathrm{E}+03$ & - \\
\hline & Streptococcus porcinus & $3.7 \mathrm{E}+07$ & - & $5.6 \mathrm{E}+07$ & - & $2.2 \mathrm{E}+03$ & $4.9 \mathrm{E}+03$ \\
\hline & Arcanobacterium heamolyticum & - & - & - & - & - & $1.2 \mathrm{E}+04$ \\
\hline & Orrskovia species & - & - & - & - & - & $4.1 \mathrm{E}+04$ \\
\hline & Vibrio vulnificus & $3.0 \mathrm{E}+03$ & - & - & - & - & - \\
\hline \multirow[t]{4}{*}{8071} & Pseudomonas aeruginosa & $7.3 \mathrm{E}+03$ & $2.9 \mathrm{E}+06$ & $2.0 \mathrm{E}+06$ & $3.3 \mathrm{E}+04$ & $1.2 \mathrm{E}+06$ & $4.2 \mathrm{E}+06$ \\
\hline & Streptococcus agalactiae & $1.5 \mathrm{E}+04$ & $5.3 \mathrm{E}+05$ & $1.7 \mathrm{E}+06$ & $3.8 \mathrm{E}+06$ & $2.9 \mathrm{E}+06$ & $5.8 \mathrm{E}+06$ \\
\hline & Arcanobacterium pyogenes & $1.3 \mathrm{E}+06$ & $4.0 \mathrm{E}+07$ & $6.2 \mathrm{E}+07$ & $6.4 \mathrm{E}+06$ & $1.1 \mathrm{E}+07$ & $8.8 \mathrm{E}+07$ \\
\hline & Micrococcus luteus & $5.1 \mathrm{E}+04$ & $5.3 \mathrm{E}+05$ & $2.8 \mathrm{E}+06$ & $2.7 \mathrm{E}+05$ & $1.0 \mathrm{E}+06$ & $1.1 \mathrm{E}+06$ \\
\hline \multicolumn{8}{|c|}{ Leak-proof cuff group } \\
\hline \multirow[t]{2}{*}{903} & P. aeruginosa & $5.95 \mathrm{E}+03$ & $2.56 \mathrm{E}+02$ & $4.27 \mathrm{E}+03$ & - & - & - \\
\hline & Streptococcus alpha & $3.16 \mathrm{E}+06$ & $1.75 \mathrm{E}+03$ & $1.73 \mathrm{E}+07$ & - & - & - \\
\hline \multirow[t]{2}{*}{906} & P. aeruginosa & - & $8.11 \mathrm{E}+02$ & $2.73 \mathrm{E}+04$ & - & - & - \\
\hline & Streptococcus alpha & - & $1.53 \mathrm{E}+03$ & $1.45 \mathrm{E}+06$ & - & - & - \\
\hline \multirow[t]{3}{*}{19} & E. coli & - & $9.00 \mathrm{E}+01$ & - & - & - & - \\
\hline & Pasteurella multocida & - & $2.86 \mathrm{E}+02$ & - & - & - & - \\
\hline & Bordetella bronchiseptica & - & $1.95 \mathrm{E}+03$ & - & - & - & - \\
\hline \multirow[t]{3}{*}{21} & Sphingomonas paucimobilis & - & - & $1.08 \mathrm{E}+04$ & - & - & - \\
\hline & E. coli & - & $1.82 \mathrm{E}+04$ & $9.00 \mathrm{E}+01$ & - & - & - \\
\hline & Enterococcus faecalis & - & $1.38 \mathrm{E}+04$ & - & - & - & - \\
\hline \multirow[t]{3}{*}{25} & E. coli & - & $2.80 \mathrm{E}+01$ & - & - & - & - \\
\hline & Staphylococcus xylosus & - & $2.80 \mathrm{E}+01$ & - & - & - & - \\
\hline & Staphylococcus warneri & - & $2.80 \mathrm{E}+01$ & - & - & - & - \\
\hline $\begin{array}{l}\text { Data are presented as } \\
\text { RUL }=\text { right upper lo } \\
\text { RML }=\text { right medium } \\
\text { RLL }=\text { right lower lo } \\
\text { LUL = left upper lob } \\
\text { LML = left medium } \\
-=\text { no growth } \\
\text { LLL = left lower lob }\end{array}$ & terial lung colonization for $\mathrm{CFU} / \mathrm{g} \geq 10^{3}$. & & & & & & \\
\hline
\end{tabular}

or range (minimum to maximum). To test the hypothesis that the leak-proof cuff (exposure variable) can prevent lung bacterial colonization (outcome variable) after $72 \mathrm{~h}$ of intubation and mechanical ventilation, differences between the groups were tested as follows: (1) difference in the proportion of colonized locations cal- culated as adjusted odds ratio and $95 \%$ CI by a logistic regression analysis with robust clustering, in which the presence of lung lobe bacterial colonization was considered the outcome variable, the ETT cuff was considered the exposure variable, and the pigs were considered the cluster variable to adjust the model for the 
Table 2. Arterial Blood Gas Analyses and Physiologic Variables

\begin{tabular}{|c|c|c|c|c|c|}
\hline Variable & $\begin{array}{l}\text { Start of } \\
\text { experiment } \\
\text { (baseline), } \\
\text { median (IQR) }\end{array}$ & $\begin{array}{c}\text { End of } \\
\text { experiment }(72 \mathrm{~h}), \\
\text { median (IQR) }\end{array}$ & $\begin{array}{c}\Delta(72 \mathrm{~h} \text { vs } \\
\text { baseline }) \text {, median } \\
\text { difference }(95 \% \mathrm{CI})\end{array}$ & $\begin{array}{c}\Delta \text { of changes } \\
\text { between } 72 \mathrm{~h} \text { and } \\
\text { baseline, (leak-proof } \\
\text { cuff vs standard } \\
\text { cuff) median }(95 \% \mathrm{CI})\end{array}$ & $\begin{array}{l}P, \Delta 72 \mathrm{~h} \\
\text { to baseline } \\
\text { (leak-proof } \\
\text { cuff vs } \\
\text { standard)* }\end{array}$ \\
\hline \multicolumn{6}{|l|}{ Arterial $\mathrm{pH}$} \\
\hline Standard cuff group & $7.51(7.47-7.53)$ & $7.47(7.39-7.53)$ & $-0.030(-0.242$ to 0.098$)$ & \multirow[t]{2}{*}{$-0.006(-0.113$ to 0.391$)$} & \multirow[t]{2}{*}{.62} \\
\hline Leak-proof cuff group & $7.51(7.46-7.52)$ & $7.43(7.43-7.78)$ & $-0.035(-0.162$ to 0.392$)$ & & \\
\hline \multicolumn{6}{|l|}{$\mathrm{P}_{\mathrm{aO}_{2}} / \mathrm{F}_{\mathrm{IO}_{2}}$} \\
\hline Standard cuff group & $534(506-565)$ & $67(59-127)$ & $-476(-518$ to -67$)$ & \multirow[t]{2}{*}{$332(41-389)$} & \multirow[t]{2}{*}{$.030 \dagger$} \\
\hline Leak-proof cuff group & $578(519-580)$ & $434(313-486)$ & $-144(-286$ to -46$)$ & & \\
\hline \multicolumn{6}{|l|}{$\mathrm{P}_{\mathrm{aCO}_{2}}, \mathrm{~mm} \mathrm{Hg}$} \\
\hline Standard cuff group & $39(37-43)$ & $48(41-59)$ & $10(-5$ to 41$)$ & \multirow[t]{2}{*}{$-16(-32$ to -1$)$} & \multirow[t]{2}{*}{$.030 \dagger$} \\
\hline Leak-proof cuff group & $41(39-43)$ & $37(31-43)$ & $-6(-14$ to 11$)$ & & \\
\hline \multicolumn{6}{|l|}{ Frequency, breaths/min } \\
\hline Standard cuff group & $15(14-15)$ & $20(19-40)$ & $5(1-42)$ & \multirow[t]{2}{*}{$1(-24$ to 5$)$} & \multirow[t]{2}{*}{.91} \\
\hline Leak-proof cuff group & $16(15-16)$ & $22(21-27)$ & $6(2-13)$ & & \\
\hline \multicolumn{6}{|l|}{ Plateau pressure, $\mathrm{cm} \mathrm{H}_{2} \mathrm{O}$} \\
\hline Standard cuff group & $16(15-16)$ & $22(20-25)$ & $8(0-16)$ & \multirow[t]{2}{*}{$0(-4$ to 6$)$} & \multirow[t]{2}{*}{.91} \\
\hline Leak-proof cuff group & $15(15-16)$ & $24(24-24)$ & $8(5-12)$ & & \\
\hline \multicolumn{6}{|c|}{ Mean arterial pressure, $\mathrm{mm} \mathrm{Hg}$} \\
\hline Standard cuff group & $96(89-114)$ & $93(90-103)$ & $-2(-28$ to 57$)$ & \multirow[t]{2}{*}{$-10(-36$ to 25$)$} & \multirow[t]{2}{*}{$>.99$} \\
\hline Leak-proof cuff group & $111(105-115)$ & $93(92-105)$ & $-12(-37$ to 22$)$ & & \\
\hline \multicolumn{6}{|c|}{$\begin{array}{l}\text { no. }=8 \text { (standard cuff group); no. }=5 \text { (leak-proof cuff group). } \\
* P \text { value compares the median changes from baseline between the groups with a Mann-Whitney } U \text { test. } \\
\dagger P<.05 \text { (2-tailed). } \\
\mathrm{IQR}=\text { interquartile range }\end{array}$} \\
\hline
\end{tabular}
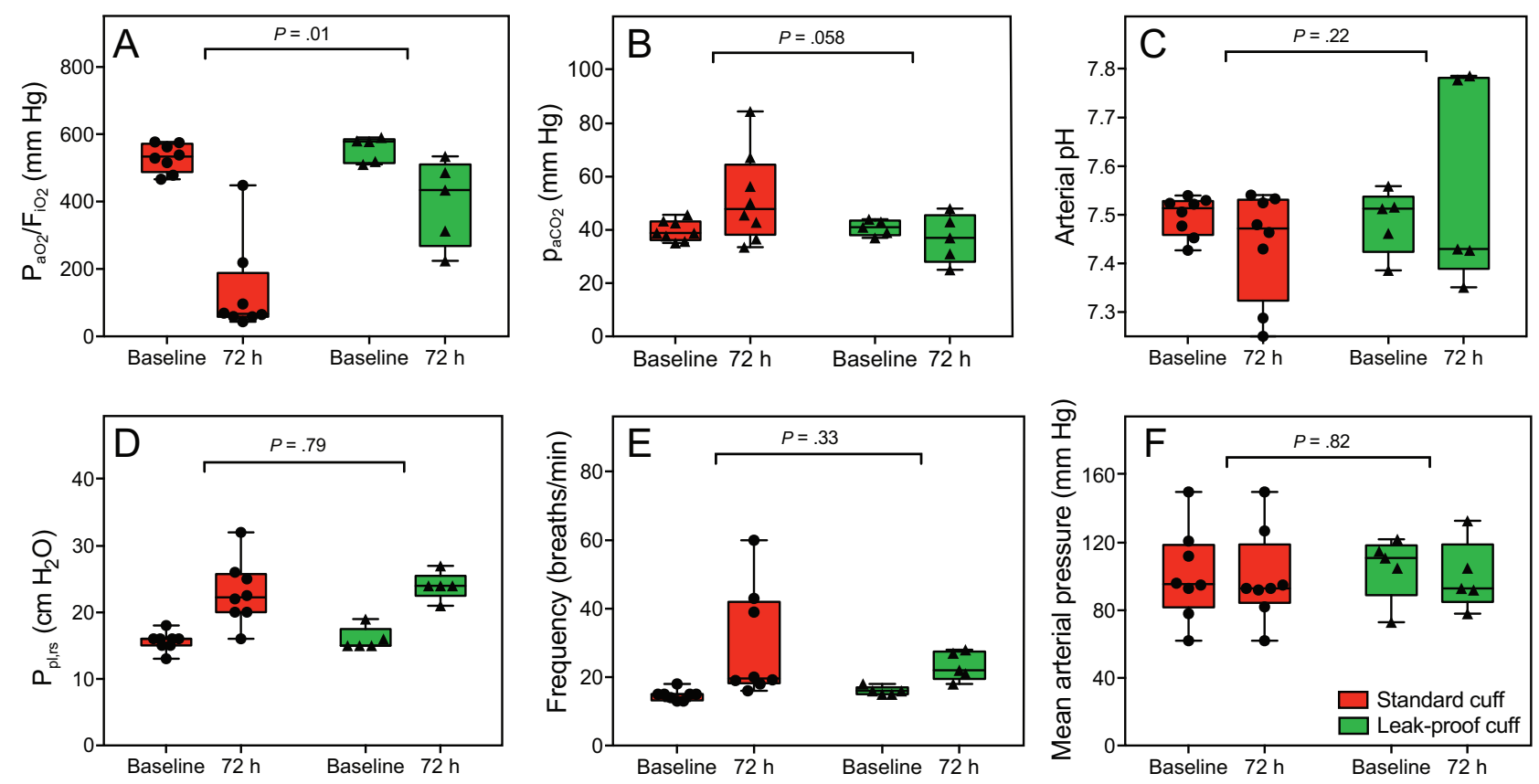

Fig. 4. Blood gas analysis and physiologic variables changes over time (from baseline to $72 \mathrm{~h}$ ) among the standard cuff group and leak-proof cuff group. A: $\mathrm{P}_{\mathrm{aO}_{2}} / \mathrm{F}_{\mathrm{IO}_{2}}$. B: $\mathrm{P}_{\mathrm{aCO}_{2}}$. C: Arterial pH. D: Respiratory system plateau pressure (Ppl,rs). E: Breathing frequency. $\mathrm{F}$ : Mean arterial pressure. Continuous variables are graphically expressed as individual data (dots), box plots (median [interquartile range]) with whiskers (range, minimum-maximum). $P$ values (2-tailed) compared groups on the mean change from baseline and were calculated with 2-way analysis of variance for repeated measurements over time. 
Table 3. Odds Ratio in the Number of Locations of Colonized Lung Lobes by Pathogenic Bacteria on Autopsy Between the Two Groups, Adjusted for Within-Animal Correlation

\begin{tabular}{|c|c|c|c|}
\hline Group & $\begin{array}{c}\text { Colonized } \\
\text { Locations/All } \\
\text { Locations, no./total }(\%)\end{array}$ & $\begin{array}{l}\text { Adjusted } \\
\text { Odds Ratio } \\
(95 \% \mathrm{CI})^{*}\end{array}$ & $P \dagger$ \\
\hline Standard cuff & $44 / 48(92 \%)$ & $0.03(0.01-0.16)$ & $<.001$ \\
\hline Leak-proof cuff & $8 / 30(27 \%)$ & & \\
\hline \multicolumn{4}{|c|}{$\begin{array}{l}\text { no. }=8 \text { (standard cuff group); no. }=5 \text { (leak-proof cuff group). } \\
* \text { The odds ratio was adjusted for the within-animal correlation on the pig level by robust } \\
\text { clustering. } \\
\dagger 2 \text {-tailed. }\end{array}$} \\
\hline
\end{tabular}

within-animal correlation (primary end point) (Table 3); (2) median difference and $95 \%$ CI of the median bacterial loads of the lung lobes (lung lobe level) within different animals (pig level) between leak-proof and standard cuff group, with the $P$ value calculated by using the Mann-Whitney $U$ test (Table 4). The median of the bacterial colonization by location (lung lobes) in both groups was depicted by using the Karnaugh color map (Fig. 5).

Methylene Blue Assessment. To evaluate the performance of the leak-proof ETT cuff in preventing macroscopic aspiration into the lower airways, the presence of methylene blue in the subglottic space of the animals was reported as count and proportion.

Statistical significance was reached with $P<.05$ (2tailed). Statistical analyses were performed by using STATA-14/MP (StataCorp, College Station, Texas), GraphPad Prism 7a (GraphPad Software, San Diego, California), and Microsoft Excel for Mac 2017, v15.32 (Microsoft Corporation, Redmond, WA).

\section{Sample-Size Calculation}

Based on previous studies from our group, ${ }^{7,9}$ we know that the leak-proof cuff was totally effective in preventing fluid leakage in vitro ${ }^{9}$ at an inflation cuff pressure at of $25-30 \mathrm{~cm} \mathrm{H}_{2} \mathrm{O}$. Furthermore, we previously demonstrated that all pigs intubated and on mechanical ventilation for $72 \mathrm{~h}$ while in the semirecumbent position showed a severe bacterial colonization at the end of experiment (100\% proportion of colonization, outcome of colonization defined as the presence of a bacterial load of $\geq 10^{3} \mathrm{CFU} / \mathrm{g}$ in the sampling locations). ${ }^{7}$ Our control group (standard cuff group) showed colonization in 44 of 48 lung lobes (92\% proportion of colonization, outcome of colonization defined as the presence of a bacterial load of $\geq 10^{3} \mathrm{CFU} / \mathrm{g}$ in the sampling locations (no. $=48,6$ lung lobes in 8 animals). ${ }^{7}$ We expected that the leak-proof cuff could effec- tively prevent lung colonization in the pigs intubated and on mechanical ventilation for $72 \mathrm{~h}$ with enteral feeding (no colonization [0\%], outcome of colonization was defined as the presence of a bacterial load of $\geq 10^{3} \mathrm{CFU} / \mathrm{g}$ in the sampling locations). When using the Fisher exact test to compare 2 independent proportions with a level of significance $(\alpha)$ of 0.05 (2-tailed) and a power $(1-\beta)$ of $90 \%$, the minimum required sample size of pigs with the experimental leak-proof cuff was no. $=5$. This article adhered to the Applicable Equator guidelines. ${ }^{18}$

\section{Results}

\section{Study Population}

Thirteen adult female Yucatan minature pigs (median (IQR) age, 8 [7-9] months; weight, 34 [27-37] kg) were studied and considered healthy based on clinical criteria, laboratory data, and chest radiographs performed the day before the experiment.

\section{Gas Exchanges and Physiologic Variables}

At baseline, we did not observe any difference in terms of gas exchange or physiologic variable measurements among the groups. In the standard cuff group, all the animals developed respiratory failure with severe hypoxemia. In the leak-proof cuff group, no animal developed respiratory failure, except one animal showed mild hypoxemia at the end of the experiment $\left(\mathrm{P}_{\mathrm{aO}_{2}} / \mathrm{F}_{\mathrm{IO}_{2}} 224 \mathrm{~mm} \mathrm{Hg}\right)$. The reduction of $\mathrm{P}_{\mathrm{aO}} / \mathrm{F}_{\mathrm{IO}_{2}}$ at $72 \mathrm{~h}$ in the standard cuff group was significantly greater compared with the $\mathrm{P}_{\mathrm{aO}} / \mathrm{F}_{\mathrm{IO}_{2}}$ decrease in the leak-proof cuff group (leak-proof cuff group vs standard cuff group, median [95\% CI] difference of changes of $\mathrm{P}_{\mathrm{aO}_{2}} / \mathrm{F}_{\mathrm{IO}_{2}}$ from baseline, 332 [41-389] mm $\mathrm{Hg}$, $P=.030[P$ value compared the median differences from $72 \mathrm{~h}$ to baseline between the two groups]) (Fig. 4A and Table 2).

Despite the effort to adjust mechanical ventilation to reach a stable $\mathrm{P}_{\mathrm{aCO}_{2}}$ of $\sim 40 \mathrm{~mm} \mathrm{Hg}$ over time, $\mathrm{P}_{\mathrm{aCO}_{2}}$ at $72 \mathrm{~h}$ increased from baseline in the standard cuff group compared with a substantial $\mathrm{P}_{\mathrm{aCO}}$ stability in the leakproof cuff group (leak-proof vs standard cuff groups, median difference of changes of $\mathrm{P}_{\mathrm{aCO}_{2}}$ from baseline -16 , $95 \% \mathrm{CI}-32$ to $-1 \mathrm{~mm} \mathrm{Hg} ; P=.030[P$ value compared the differences from $72 \mathrm{~h}$ to baseline between the two groups]) (Fig. 4B and Table 2).

This happened despite breathing frequency increasing in the standard cuff group by a median $5,95 \%$ CI $1-42 ; P=.015$ breaths/min at $72 \mathrm{~h}$ from baseline, whereas the breathing frequency did not significantly change at $72 \mathrm{~h}$ compared with baseline in the leak-proof cuff group (frequency, median difference of the differences from $72 \mathrm{~h}$ to baseline 
Table 4. Median Difference (95\% CI) of the Median Bacterial Loads of the Lung Lobes Within Different Animals on Autopsy Between the Two Groups

\begin{tabular}{lcc}
\hline \hline \multicolumn{1}{c}{ Group } & Median Lung Lobes Bacterial Load, median (IQR) & Median Difference (95\% CI) \\
\hline Standard cuff group & $4.5 \times 10^{7}\left(1.5 \times 10^{6}\right.$ to $\left.1.9 \times 10^{8}\right)$ & $-4.5 \times 10^{7}\left(-2.2 \times 10^{8}\right.$ to $\left.-9.3 \times 10^{5}\right)$ \\
Leak-proof cuff group & $0\left(0\right.$ to $\left.5 \times 10^{2}\right)$ & .002 \\
& & \\
no. $=8$ (standard cuff group); no. $=5$ (leak-proof cuff group). \\
$\dagger 2$-tailed. \\
$\mathrm{IQR}=$ interquartile range
\end{tabular}

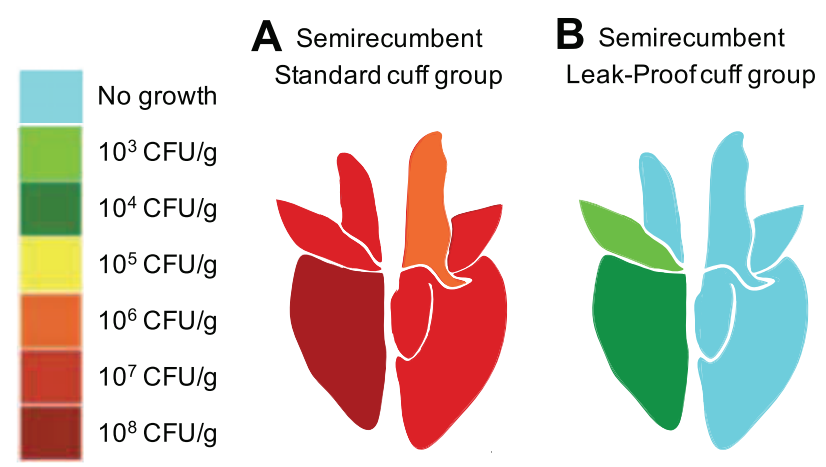

Fig. 5. Median of bacterial colonization (CFU/g) in the standard cuff group (A) and in the leak-proof cuff group (B) by location into the lung lobes.

among the groups $1,95 \% \mathrm{CI}-24$ to 5 breaths/min; $P=.91$ $[P$ value compared the differences from $72 \mathrm{~h}$ to baseline between the two groups]) (Fig. 4E and Table 2). Arterial $\mathrm{pH}$ remained stable throughout the experiment in both groups (Fig. 4C and Table 2). Similarly, the respiratory system plateau pressure significantly increased from baseline to $72 \mathrm{~h}$ both in the standard cuff group $(P=.001)$ and in the leak-proof cuff group $(P=.004)$ (Fig. 4D and Table 2 ). We did not observe any significant difference in mean arterial pressure over time and between the 2 groups (Fig. 4F and Table 2).

\section{Microbiologic Colonization}

The sampling sites are highlighted in Figure 3. In the standard cuff group, 6 of 8 animals (nos. 5621, 5639, $5644,5661,8057,8071)$ were heavily colonized by different bacteria (bacteria range within the pig level [2, 7] (minimum to maximum) in all 6 lung lobes [range $1.0 \times 10^{3}$ to $\left.\left.2.7 \times 10^{9} \mathrm{CFU} / \mathrm{g}\right]\right)$. The remaining 2 minature pigs showed bacterial colonization (bacteria range within the pig level [2, 3] (minimum to maximum) in 4 of 6 lung lobes (no. 5620, bacterial load range of $3.6 \times 10^{3}$ to $5.2 \times 10^{7} \mathrm{CFU} / \mathrm{g}$ in 4 colonized lung lobes; no. 5652, bacterial load range of $1.2 \times 10^{3}$ to $3.2 \times 10^{3} \mathrm{CFU} / \mathrm{g}$ in 4 colonized lung lobes) (Table 1 ).

In the leak-proof cuff group, pig no. 25 did not present sufficient bacterial load to meet criteria of colonization ( 28
CFU/g by 3 bacteria in the right middle lobe). Animal no. 19 presented with mild colonization $\left(1.95 \times 10^{3} \mathrm{CFU} / \mathrm{g}\right)$ by a single bacterium (Bordetella bronchiseptica) in just 1 of 6 lung lobes. Pigs nos. 906 and 21 showed bacterial colonization (bacteria range within the pig level [2, 3] (minimum to maximum) in 2 of 6 lung lobes [nos. 906 and 21 ; bacterial load range of 2 colonized lung lobes within the pig level $\left(1.53 \times 10^{3}\right.$ to $\left.\left.1.45 \times 10^{6} \mathrm{CFU} / \mathrm{g}\right)\right]$. Pig no. 903 presented colonization by 2 bacteria in 3 of 6 lobes (bacterial load range within 3 colonized lung lobes of $1.75 \times 10^{3}$ to $1.73 \times 10^{7} \mathrm{CFU} / \mathrm{g}$ ) (Table 1$)$.

The standard cuff group presented with a significantly greater colonization compared with the leak-proof cuff group, either in the number of locations or in the bacterial load. In the standard cuff group, the overall amount of colonized locations in all 8 animals was significantly greater compared with the number of colonized locations in the 5 animals of the leak-proof cuff group (fraction of colonized sampling locations, leak-proof cuff group vs standard cuff group, 27\% vs 92\%; adjusted odds ratio 0.03 , 95\% CI $0.01-0.16 ; P<.001[P$ value of the risk of lung lobes colonization when accounting for the number of animals between the groups] (Table 3). The median (interquartile range) of the median bacterial loads of the 6 lung lobes calculated in each animal in the standard cuff group was considerably greater compared with the median bacterial loads of the lung lobes assessed in the 5 animals of the leak-proof cuff group (leak-proof vs standard cuff group, median difference $(95 \% \mathrm{CI})$ of the median bacterial loads calculated at the animal level was median $-4.5 \times 10^{7}$, $95 \% \mathrm{CI}-2.2 \times 10^{8}$ to $-9.3 \times 10^{5} ; P=.002$ (Table 4 ). The median bacterial colonization of the respiratory system by location in the 2 groups are illustrated in Figure $3 \mathrm{~A}$ (standard cuff group) and B (leak-proof cuff group) by using the Karnaugh color map.

\section{Methylene Blue Assessment, Enteral Nutrition, and Regurgitation}

We performed the methylene blue assessment below the ETT cuff in the leak-proof cuff group. None of the 5 animals exhibited any presence of methylene blue along the trachea (0\% [0/5 animals]). Furthermore, we did not detect 


\section{Prevention of Colonization With a Leak-Proof ETT Cuff}

any regurgitation during enteral feeding throughout all the animal experiments in both the leak-proof and the standard cuff group.

\section{Discussion}

In this experimental pig model, we investigated the effect of a double-layer guayule latex leak-proof cuff on lung bacterial colonization and blood gas values after intubation, $72 \mathrm{~h}$ of mechanical ventilation, and continuous enteral feeding. The principal finding of our investigation was that an ETT with a leak-proof cuff prevented lung bacterial colonization compared with an ETT with a standard high-volume low-pressure PVC cuff. The microbiologic data of lung colonization in the leak-proof cuff group was reinforced by the absence of methylene blue in the tracheal secretions at the macroscopic evaluation.

In a bench-top in vitro trachea study that compared the ability of ETTs with different sealing cuffs to prevent fluid leakage, our group observed that the double-layer guayule latex leak-proof cuff was able to provide an effective sealing of a cylindrical glass tube. Contrarily, the standard high-volume low-pressure PVC cuffs did not effectively prevent the fluid leakage across the cuff. The difference in the average leakage flow among the 2 different cuffs was even more striking when the intra-cuff pressure was maintained as low as $20 \mathrm{~cm} \mathrm{H}_{2} \mathrm{O}$, and the leak-proof cuff still showed excellent sealing properties. The prototype experimental cuff has a unique mechanical property. The thin guayule latex layer was highly compliant and, when the double-layer cuff was inflated, did not present any folds along the surface. This translated to a physical advantage of the leak-proof cuff, which could prevent the fluid leakage across the cuff. On the contrary, the commercial highvolume low-pressure cuffs had folds along their surface, which allowed fluid leakage across the cuff caused by incomplete sealing of the in vitro trachea. ${ }^{9-11}$ Our results confirmed in vivo the efficacy of the prototype leak-proof cuff in preventing subglottic secretion leakage for the first time and, hence, in blocking the pathway to lung bacterial colonization. Therefore, although we could not exclude the presence of microaspiration because the bacterial load in the leak-proof cuff group was not abolished but remarkably decreased, the use of a macroscopic technique such as the methylene blue evaluation in the trachea indicated that a double-layer guayule cuff prevented leakage by averting macroaspiration.

Many factors are involved in the process that leads to lung colonization during mechanical ventilation. All of these factors are linked to the ETT, the key factor of lung parenchyma colonization. Colonized subglottic secretions that leak across the folds of the ETT cuff, 7 ineffective mucociliary clearance caused by the cuff, 5 impairment of the protective cough reflex after endotracheal intubation, ${ }^{19}$ aerosolization of the biofilm along the inner surface of the ETT that acts as a bacterial reservoir, ${ }^{20}$ and the development of atelectasis ${ }^{21}$ all contribute to increase the risk of lung colonization and, eventually, pneumonia. Furthermore, in the semirecumbent position, gravity directly acts on lung colonization and pneumonia, as described in both animal models ${ }^{4,7,8,22}$ and human subjects, ${ }^{23,24}$ and as recently confirmed by the Gravity-trial Network. ${ }^{24}$ As shown in clinical studies, although the shape does not affect the frequency of pneumonia, ${ }^{25,26}$ the material of the ETT cuff can exhibit a different performance in terms of pneumonia prevention. ${ }^{27-29}$ Of note, no animals in the leak-proof cuff group showed colonization of the left lobes. On the contrary, colonization was mostly present in the right middle and lower lobes, which suggested a gravitational effect on the development of colonization and confirmed previous findings reported by Li Bassi et al. ${ }^{30}$

Our pig model was suitable to consider a translation of the results into clinical practice because pigs are omnivores and share a similar physiology of the gastrointestinal tract to humans. ${ }^{31}$ However, even without bacteria inoculation in the trachea, lung bacterial colonization was most likely enhanced by a series of factors of the animal model studied, that is (1) prolonged intubation in semirecumbent position; (2) the position of the trachea below the esophagus further increased the likelihood of pooled secretions leaking into the subglottic area rather than into the esophagus; (3) a lack of oropharyngeal disinfection and antibiotic administration; and (4) a relevant bacterial load of the oropharyngeal flora compared with humans. Despite this, we observed that the use of a double-layer guayule cuff was able to substantially prevent lung bacterial colonization compared with a high-volume low-pressure PVC cuff.

A second finding in our investigation was the observation that the double-layer leak-proof cuff could prevent a significant worsening of the $\mathrm{P}_{\mathrm{aO}}$ compared with a standard high-volume low-pressure PVC cuff after $72 \mathrm{~h}$ of mechanical ventilation. Although the leak-proof cuff group presented a normal $\mathrm{P}_{\mathrm{aO}_{2}}$ at the end of the experiment, the standard cuff group presented with severe hypoxemia. Furthermore, in the standard cuff group, all the animals presented with respiratory distress, with a significant increase in breathing frequency to maintain normal $\mathrm{P}_{\mathrm{aCO}}$ levels. The difference in terms of lung lobe colonization among the groups could explain the difference in the blood gas variables between the 2 groups. Previous studies in sheep in the semirecumbent position showed a high incidence of lung colonization. This caused inflammation of the lung parenchyma and led to hypoxemia, a pathophysiologic sign of respiratory failure. ${ }^{4,5,7,8}$ Results of our study indicated that the change of a single variable during intubation and mechanical ventilation (ETT cuff) might play a major contributing role in the multifaceted pathogenesis of VAP 


\section{Prevention of Colonization With a Leak-Proof ETT Cuff}

because it can radically influence the risk of lung bacterial colonization.

A double-layer guayule latex leak-proof cuff effectively sealed the trachea because of the lack of folds within its surface, and this eventually prevented the development of acute hypoxemic respiratory failure and maintained the blood gas values within normal ranges. This finding was of potential clinical interest when also considering the relative minimum cost of the ETT cuff in a clinical scenario of high VAP health-care-associated costs. ${ }^{32}$ Of note, the outer layer of the leak-proof cuff was composed of guayule latex material, in which the presence of protein was negligible, which also makes it suitable for subjects who are latex sensitive. ${ }^{33,34}$

This animal work had several limitations that we should take into account. First of all, the study specifically focused on lung colonization and blood gas values without considering the clinical criteria of pneumonia, analyses of tissue macroscopy, and histopathology. Second, the 2 animal groups were not randomized. In the leak-proof cuff all 5 animals received enteral feeding, whereas 2 of 8 animals of our historical control (standard cuff group) received enteral feeding, which is an established risk factor of lung colonization and pneumonia. ${ }^{13-16,35}$ Enteral feeding might have allowed an underestimation of the efficacy of the leak-proof cuff in preventing lung bacterial colonization. Third, we did not analyze the bacteria of the oropharyngeal flora to determine whether there was any correlation with the bacteria reported in the lungs of the animals or if there had been any change in the nature of the bacterial species in the oropharynx from the beginning until the end of the experiment. Fourth, methylene blue evaluation by bronchoscopy was not performed in the historical control group. However, frequent cuff pressure checks (ie, range $25-30 \mathrm{~cm} \mathrm{H}_{2} \mathrm{O}$ ) and the delivered PEEP (ie, $5 \mathrm{~cm} \mathrm{H}_{2} \mathrm{O}$ ) were performed to maintain the same experimental conditions of the control group.

\section{Conclusions}

This study aimed to clarify, for the first time to our knowledge, the in vivo efficacy of a leak-proof cuff in the prevention of lung colonization after $72 \mathrm{~h}$ of mechanical ventilation in pigs by simulating the semirecumbent position of patients in the ICU. The results of the present animal investigation indicated that an ETT with a leakproof cuff could effectively prevent lung colonization by completely sealing the trachea, which stopped the leakage of the subglottic secretions into the airways. This effect prevented respiratory failure and hypoxemia in our pig animal model. Future human feasibility and/or efficacy studies aimed at confirming the prevention of VAP and use of the leak-proof cuff for a prolonged period of time $(>72 \mathrm{~h})$ are warranted.

\section{ACKNOWLEDGMENTS}

We thank Dr Robert F Hoyt, Randall Clevenger, Kelly Cole, Dave Caden, Phyllis Levin, Arthur Zetts, Timothy Hunt, Kenneth Jeffries, Karen Keeran, Gayle Zywicke, and Danielle Springer for their assistance throughout the animal studies. We thank Dr Katrina Cornish and Jali Williams (Yulex Corporation, Maricopa, Arizona) for manufacturing and providing the double-layer guayule latex leak-proof cuff to the authors without charge and without additional financial support.

\section{REFERENCES}

1. Hunter JD. Ventilator associated pneumonia. BMJ 2012;344:e3325.

2. Melsen WG, Rovers MM, Groenwold RH, Bergmans DC, Camus C, Bauer TT, et al. Attributable mortality of ventilator-associated pneumonia: a meta-analysis of individual patient data from randomised prevention studies. Lancet Infect Dis 2013;13(8):665-671.

3. Ramirez P, Ferrer M, Torres A. Prevention measures for ventilatorassociated pneumonia: a new focus on the endotracheal tube. Curr Opin Infect Dis 2007;20(2):190-197.

4. Panigada M, Berra L, Greco G, Stylianou M, Kolobow T. Bacterial colonization of the respiratory tract following tracheal intubationeffect of gravity: an experimental study. Crit Care Med 2003;31(3): 729-737.

5. Li Bassi G, Zanella A, Cressoni M, Stylianou M, Kolobow T. Following tracheal intubation, mucus flow is reversed in the semirecumbent position: possible role in the pathogenesis of ventilatorassociated pneumonia. Crit Care Med 2008;36(2):518-525.

6. Mauri T, Berra L, Kumwilaisak K, Pivi S, Ufberg JW, Kueppers F, et al. Lateral-horizontal patient position and horizontal orientation of the endotracheal tube to prevent aspiration in adult surgical intensive care unit patients: a feasibility study. Respir Care 2010;55(3):294302.

7. Zanella A, Cressoni M, Epp M, Hoffmann V, Stylianou M, Kolobow T. Effects of tracheal orientation on development of ventilator-associated pneumonia: an experimental study. Intensive Care Med 2012; 38(4):677-685.

8. Rezoagli E, Zanella A, Cressoni M, De Marchi L, Kolobow T, Berra L. Pathogenic link between postextubation pneumonia and ventilator-associated pneumonia: an experimental study. Anesth Analg 2017; 124(4):1339-1346.

9. Zanella A, Cressoni M, Epp M, Stylianou M, Kolobow T. A doublelayer tracheal tube cuff designed to prevent leakage: a bench-top study. Intensive Care Med 2008;34(6):1145-1149.

10. Zanella A, Scaravilli V, Isgrò S, Milan M, Cressoni M, Patroniti N, et al. Fluid leakage across tracheal tube cuff, effect of different cuff material, shape, and positive expiratory pressure: a bench-top study. Intensive Care Med 2011;37(2):343-347.

11. Kolobow T, Cressoni M, Epp M, Corti I, Cadringher P, Zanella A. Comparison of a novel lycra endotracheal tube cuff to standard polyvinyl chloride cuff and polyurethane cuff for fluid leak prevention. Respir Care 2011;56(8):1095-1099.

12. National Institutes of Health: Guide for the Care and Use of Laboratory Animals. NIH Publication No. 86-23. Washington, DC: U.S. Government Printing Office; 1985.

13. Torres A, el-Ebiary M, González J, Ferrer M, Puig de la Bellacasa J, Gené A, et al. Gastric and pharyngeal flora in nosocomial pneumonia acquired during mechanical ventilation. Am Rev Respir Dis 1993; 148(2):352-357.

14. Orozco-Levi M, Torres A, Ferrer M, Piera C, el-Ebiary M, de la Bellacasa JP, Rodriquez-Roisin R. Semirecumbent position protects from pulmonary aspiration but not completely from gastroesophageal reflux in mechanically ventilated patients. Am J Respir Crit Care Med 1995;152(4 Pt 1):1387-1390. 


\section{Prevention of Colonization With a Leak-Proof ETT Cuff}

15. Torres A, El-Ebiary M, Soler N, Montón C, Fàbregas N, Hernández C. Stomach as a source of colonization of the respiratory tract during mechanical ventilation: association with ventilator-associated pneumonia. Eur Respir J 1996;9(8):1729-1735.

16. Montecalvo MA, Steger KA, Farber HW, Smith BF, Dennis RC, Fitzpatrick GF, et al. Nutritional outcome and pneumonia in critical care patients randomized to gastric versus jejunal tube feedings. The Critical Care Research Team. Crit Care Med 1992;20(10):1377-1387.

17. https://eur-lex.europa.eu/legal-content/EN/TXT/?uri=celex $\% 3 \mathrm{~A} 3$ 2010L0063. Accessed March 4, 2019

18. Kilkenny C, Browne WJ, Cuthill IC, Emerson M, Altman DG. Improving bioscience research reporting: the ARRIVE guidelines for reporting animal research. PLoS Biol 2010;8(6):e1000412.

19. Tanaka A, Isono S, Ishikawa $T$, Nishino $T$. Laryngeal reflex before and after placement of airway interventions: endotracheal tube and laryngeal mask airway. Anesthesiology 2005;102(1):20-25.

20. Li Bassi G, Fernandez-Barat L, Saucedo L, Giunta V, Marti JD, Tavares Ranzani O, et al. Endotracheal tube biofilm translocation in the lateral Trendelenburg position. Crit Care 2015;19:59.

21. van Kaam AH, Lachmann RA, Herting E, De Jaegere A, van Iwaarden F, Noorduyn LA, et al. Reducing atelectasis attenuates bacterial growth and translocation in experimental pneumonia. Am J Respir Crit Care Med 2004;169(9):1046-1053.

22. Crouch TW, Higuchi JH, Coalson JJ, Johanson WG Jr. Pathogenesis and prevention of nosocomial pneumonia in a nonhuman primate model of acute respiratory failure. Am Rev Respir Dis 1984;130(3): 502-504.

23. Girou E, Buu-Hoi A, Stephan F, Novara A, Gutmann L, Safar M, Fagon JY. Airway colonisation in long-term mechanically ventilated patients. Effect of semi-recumbent position and continuous subglottic suctioning. Intensive Care Med 2004;30(2):225-233.

24. Li Bassi G, Panigada M, Ranzani OT, Zanella A, Berra L, Cressoni M, et al.; GRAVITY-VAP Network. Randomized, multi-center trial of lateral Trendelenburg versus semi-recumbent body position for the prevention of ventilator-associated pneumonia. Intensive Care Med 2017;43(11):1572-1584.

25. Philippart F, Gaudry S, Quinquis L, Lau N, Ouanes I, Touati S, et al.; TOP-Cuff Study Group. Randomized intubation with polyurethane or conical cuffs to prevent pneumonia in ventilated patients. Am J Respir Crit Care Med 2015;191(6):637-645.

26. Monsel A, Lu Q, Le Corre M, Brisson H, Arbelot C, Vezinet C, et al.; TETRIS Study Group. Tapered-cuff endotracheal tube does not prevent early postoperative pneumonia compared with sphericalcuff endotracheal tube after major vascular surgery: a randomized controlled trial. Anesthesiology 2016;124(5):1041-1052.

27. Miller MA, Arndt JL, Konkle MA, Chenoweth CE, Iwashyna TJ, Flaherty KR, Hyzy RC. A polyurethane cuffed endotracheal tube (PUC-ETT) is associated with decreased rates of ventilator-associated pneumonia. J Crit Care 2011;26(3):280-286

28. Poelaert J, Depuydt P, De Wolf A, Van de Velde S, Herck I, Blot S. Polyurethane cuffed endotracheal tubes to prevent early postoperative pneumonia after cardiac surgery: a pilot study. J Thorac Cardiovasc Surg 2008;135(4):771-776.

29. Lorente L, Lecuona M, Jiménez A, Mora ML, Sierra A. Influence of an Endotracheal tube with polyurethane cuff and subglottic secretion drainage on pneumonia. Am J Respir Crit Care Med 2007;176(11): 1079-1083.

30. Li Bassi G, Rigol M, Marti JD, Saucedo L, Ranzani OT, Roca I, et al. A novel porcine model of ventilator-associated pneumonia caused by oropharyngeal challenge with Pseudomonas aeruginosa. Anesthesiology 2014;120(5):1205-1215.

31. Luna CM, Sibila O, Agusti C, Torres A. Animal models of ventilator-associated pneumonia. Eur Respir J 2009;33(1):182-188.

32. Branch-Elliman W, Wright SB, Howell MD. Determining the ideal strategy for ventilator-associated pneumonia prevention. Cost-benefit analysis. Am J Respir Crit Care Med 2015;192(1):57-63.

33. Siler DJ, Cornish K, Hamilton RG. Absence of cross-reactivity of $\mathrm{IgE}$ antibodies from subjects allergic to Hevea brasiliensis latex with a new source of natural rubber latex from guayule (Parthenium argentatum). J Allergy Clin Immunol 1996;98(5 Pt 1):895-902.

34. Siler DJ, Cornish K. Hypoallergenicity of guayule rubber particle proteins compared to Hevea latex proteins. Ind Crops Prod 1994; 2(4):307-313. Available at https://www.sciencedirect.com/science/ article/pii/0926669094901228.

35. Cook DJ, Walter SD, Cook RJ, Griffith LE, Guyatt GH, Leasa D, et al. Incidence of and risk factors for ventilator-associated pneumonia in critically ill patients. Ann Intern Med 1998;129(6):433-440.

This article is approved for Continuing Respiratory Care Education credit. For information and to obtain your CRCE

(free to AARC members) visit www.rcjournal.com

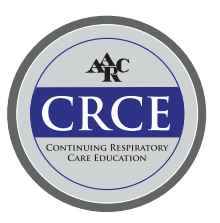

